\title{
Pengaruh Kompos Ela Sagu dengan Mikroorganisme Antagonis Terhadap Kemasaman, P-Tersedia dan N-Total Tanah pada Ultisols
}

\author{
Effect of Sago Palm Waste Compost with Microorganisms Antagonists on Acidity, P-Available and \\ $N$-Total on Ultisols
}

\author{
Elizabeth Kaya ${ }^{1, *}$, Arni Buton ${ }^{2}$ \\ ${ }^{1}$ Jurusan Budidaya Pertanian, Fakultas Pertanian, Universitas Pattimura, Jl. Ir. M. Putuhena, Kampus Poka, Ambon \\ 97233, Indonesia \\ ${ }^{2}$ Alumni Program Studi Agroteknologi, Fakultas Pertanian, Universitas Pattimura, Jl. Ir. M. Putuhena, Kampus Poka, \\ Ambon 97233, Indonesia \\ *E-mail Penulis Korespondensi: elizabethkaya712@ gmail.com
}

\begin{abstract}
Agricultural waste, such as sago 'ela' or sago extraction waste, can be used as an organic fertilizer to improve the physical, chemical and biological properties of the soil. In addition to organic fertilizer from sago 'ela', microorganisms can also be used to increase soil fertility. The purpose of this study was to examine the effect of sago 'ela' compost and antagonistic microorganisms in the process of changing acidity ( $\mathrm{pH}$ and Al-exc), availability of P, and total $N$ in Ultisols soil. The research took place at the Laboratory of Soil, Water, and Plant Analysis, Faculty of Agriculture, Pattimura University, Ambon, in June - September 2016. The experiment was carried out with a completely randomized design (CRD) with a factorial arrangement of $4 \times 3$, with 3 replications. The treatments of providing sago 'ela' compost consisted of: no compost (K0), $15 \mathrm{~g} / \mathrm{kg}$ of soil (K1), 22, $5 \mathrm{~g} / \mathrm{kg}$ of soil (K2), $30 \mathrm{~g} / \mathrm{kg}$ of soil (K3). Inoculum provision of antagonistic microorganisms consisted of: without inoculum (AO), Trichoderma sp inoculum $20 \mathrm{~mL}$ (Al), and Azotobacter sp inoculum $20 \mathrm{~mL}$ (A2). The experiment used 3 replications. The results showed that soil pH was increased by compost and antagonistic microorganisms. However, the effect of compost does not depend on the presence or absence of antagonistic microorganisms and vice versa. Al-exc concentrations were reduced by compost and microorganisms, but the effect of microorganisms only occurred in the soil without compost and in the treatment of $15 \mathrm{~g} / \mathrm{kg}$ of soil (K1). Above these compost doses, the effect of microorganisms was not significant. The concentrations of available $P$ and total soil $N$ were increased by compost and microorganisms, and the effect of compost was greater if accompanied by the application of Azotobacter sp.
\end{abstract}

Keywords: acid soil, antagonistic microorganisms, compost, sago 'ela'

\begin{abstract}
ABSTRAK
Limbah pertanian, seperti ela sagu atau limbah ekstraksi sagu, dapat digunakan sebagai bahan pupuk organik untuk memperbaiki sifat fisik, kimia dan biologi tanah. Selain pupuk organik dari ela sagu, mikroorganisme juga dapat digunakan untuk meningkatkan kesuburan tanah. Tujuan penelitian ini adalah untuk mengkaji pengaruh pemberian kompos ela sagu dan mikroorganisme antagonis dalam proses perubahan kemasaman ( $\mathrm{pH}$ dan $\mathrm{Al}$-dd), ketersediaan $\mathrm{P}$, dan $\mathrm{N}$ total pada tanah Ultisols. Penelitian berlangsung di Laboratorium Analisis Tanah, Air, dan Tanaman Fakultas Pertanian, Universitas Pattimura Ambon, pada bulan Juni - September 2016. Percobaan dilakukan dengan Rancangan Acak Lengkap dengan pola faktorial $4 \times 3$, dengan tiga ulangan. Perlakuan pemberian kompos ela sagu terdiri atas: tanpa kompos (K0), $15 \mathrm{~g} / \mathrm{kg}$ tanah (K1), 22,5 g/kg tanah (K2), $30 \mathrm{~g} / \mathrm{kg}$ tanah (K3). Pemberian inokulum mikroorganisme antagonis terdiri atas: tanpa inokulum (A0), inokulum Trichoderma sp $20 \mathrm{~mL}$ (A1), dan inokulum Azotobacter sp 20 $\mathrm{mL}$ (A2), Percobaan menggunakan 3 ulangan. Hasil penelitian menunjukkan bahwa pH tanah ditingkatkan oleh kompos dan mikroorganisme antagonis. Tetapi, pengaruh kompos tidak tergantung pada ada atau tidak adanya mikroorganisme antagonis dan sebaliknya. Kosentrasi Al-dd diturunkan oleh kompos dan mikroorganisme, tetapi pengaruh mikroorganisme hanya terjadi pada tanah yang tidak diberi kompos dan pada perlakuan $15 \mathrm{~g} / \mathrm{kg} \operatorname{tanah}(\mathrm{K} 1)$. Di atas dosis kompos tersebut pengaruh mikroorganisme tidak nyata. Konsentrasi $\mathrm{P}$ tersedia dan $\mathrm{N}$ total tanah ditingkatkan oleh kompos dan mikroorganisme, dan pengaruh kompos lebih besar jika disertai pemberian Azotobacter sp.
\end{abstract}

Kata kunci: 'ela' sagu, kompos, mikroorganisme antagonis, tanah masam 


\section{PENDAHALUAN}

Pembangunan pertanian meningkatkan produksi dan pendapatan petani serta mempertahankan swasembada pangan saat ini menghadapi tantangan yang semakin berat. Meningkatnya permintaan hasil pertainan karena bertambahnya jumlah penduduk dan menyusutnya lahan untuk berbagai keperluan non pertanian, menyebabkan pengembangan pertanian diarahkan pada pemanfaatan lahan marginal, seperti tanah podsolik.

Ultisol merupakan tanah mineral bereaksi masam, mengalami pencucian intensif, pada lapisan atas berwarna abu-abu muda sampai kekuningan, lapisan bawah merah atau kuning, terdapat akumulasi liat hingga tekstur relatif berat (kadar liat tinggi), struktur gumpal, permeabilitas rendah, stabilitas agregat rendah, bahan organik rendah, kejenuhan basa rendah, $\mathrm{pH}$ rendah sekitar 4,2-4,8 (Hardjowigeno, 1995). Khususnya di Maluku, tanah Ultisol memiliki $\mathrm{pH}$ rendah, dominan liat, produktivitasnya rendah, kesuburan fisik dan kimianya juga rendah. Hal ini sesuai dengan hasil penelitian Kaya et al. (2010) dan Soplanit (2011) yang menyatakan bahwa tanah Ultisol memiliki reaksi tanah/ $\mathrm{pH}$ tanah yang masam (4,7), kandungan $\mathrm{Al}$ tinggi, yaitu 4,47 me/100 g, dan kesuburan kimiawi yang rendah atau miskin akan unsur hara dengan kejenuhan basa $11,0 \%$ dan KTK 19,75 me/100 g.

Telah banyak usaha yang dilakukan untuk dapat meningkatkan produktivitas Ultisol seperti penggunaan pupuk buatan seperti urea dan TSP/SP-36. Namun penggunaan pupuk buatan tersebut memerlukan biaya dan energi yang relatif besar. Selain itu, juga menimbulkan dampak negatif terhadap lingkungan. Salah satu tindakan mengatasi masalah tersebut adalah menggunakan bahan organik. Bahan organik berperan penting dalam memperbaiki sifat-sifat fisik, kimia dan biologi tanah. Pengaruh bahan organik terhadap sifat kimia tanah diantaranya terhadap $\mathrm{pH}$ tanah, ketersediaan $\mathrm{P}$, ketersediaan N total tanah (Sanchez, 1992; Kaya, 2003).

Selain pupuk kompos ela sagu, mikroorganisme juga dapat digunakan untuk meningkatkan kesuburan tanah. Mikroorganisme tanah merupakan faktor penting dalam ekosistem tanah, karena berpengaruh terhadap siklus dan ketersediaan hara tanaman serta stabilitas struktur tanah, juga dapat digunakan sebagai antagonis/ penghambat bagi kehidupan mikroorganisme patogen tanaman (Susilawati, 2013). Dalam penelitian ini mikroorganisme antagonis yang digunakan adalah Azotobacter sp dan Trichoderma sp. Tujuan dari penelitian ini adalah untuk mengkaji pengaruh pemberian kompos ela sagu dan dua mikroorganisme antagonis tersebut dalam proses perubahan kemasaman ( $\mathrm{pH}$ dan Al-dd), ketersediaan $\mathrm{P}$, dan $\mathrm{N}$ total pada tanah Podsolik.

\section{BAHAN DAN METODE}

Penelitian ini dilaksanakan di Laboratorium Analisis Tanah, Air, dan Tanaman Fakultas Pertanian,
Universitas Pattimura, Ambon; dan berlangsung dari bulan Juni-September 2016. Analisis kimia tanah dilakukan di Laboratorium Instalasi Tanah, Maros. Penelitian ini dilakukan dengan percobaan menggunakan rancangan acak lengkap dengan pola faktorial $4 \times 3$, dan dengan tiga ulangan, sehingga terdapat 36 satuan percobaan. Faktor pertama adalah pemberian pupuk organik (kompos ela sagu) yang terdiri atas empat taraf, yaitu: $\mathrm{K} 0=$ kontrol, $\mathrm{K} 1=30 \mathrm{ton} / \mathrm{ha}(15 \mathrm{~g} / \mathrm{kg}$ tanah $), \mathrm{K} 2$ $=45 \mathrm{ton} / \mathrm{ha}(22,5 \mathrm{~g} / \mathrm{kg} \tan \mathrm{h}), \mathrm{K} 3=60 \mathrm{ton} / \mathrm{ha}(30 \mathrm{~g} / \mathrm{kg}$ tanah); dan faktor kedua adalah pemberian inokulum mikroorganisme antagonis, terdiri atas tiga taraf perlakuan yaitu: $\mathrm{A} 0=$ tanpa pemberian inokulum mikroorganisme, A1 = inokulum Trichoderma sp. 20 mL, A2 = inokulum Azotobacter sp. $20 \mathrm{~mL}$.

Contoh tanah yang digunakan dalam penelitian ini adalah Ultisol dari dusun Telaga Kodok yang diambil secara komposit pada kedalaman 0-30 cm dari permukaan. Selanjutnya sampel tanah ini dikeringanginkan dan kemudian diayak untuk memisahkan bahan kasar. Untuk analisis tanah awal diambil contoh tanah komposit sebanyak 200 g. Sifat-sifat tanah yang dianalisis adalah $\mathrm{pH}, \mathrm{C}$ organik, $\mathrm{N}$ total, P-tersedia, KTK, KB, kation-katoin basa, C/N, Al-dd dan tekstur tanah. Setiap ember percobaan diisi dengan sebanyak 1 $\mathrm{kg}$ tanah. Setelah itu masing-masing satuan percobaan diaplikasikan dengan perlakuan faktor pertama, yaitu pupuk kompos ela sagu dengan perlakuan untuk $\mathrm{K}_{0}=$ tanpa kompos, $\mathrm{K}_{1}=15 \mathrm{~g} / \mathrm{kg} \operatorname{tanah}, \mathrm{K}_{2}=22,5 \mathrm{~g} / \mathrm{kg}, \mathrm{K}_{3}=$ $30 \mathrm{~g} / \mathrm{kg}$. Setelah diaplikasikan tanah dibolak-balik dan diaduk dengan tujuan agar pupuk kompos menyatu dengan tanah dan lalu dibiarkan selama 7 hari. Setelah itu, dilanjutkan dengan pemberian perlakuan faktor kedua, yaitu menambahkan mikroorganisme antagonis Trichoderma sp. dan Azotobacter sp., sesuai perlakuan. Mikroorganisme antagonis diperoleh dari Laboratorium Hama dan Penyakit Fakultas Pertanian, Universitas Pattimura.

Setelah pemberian perlakuan, ember-ember percobaan ditutup dengan plastik agar kelembabannya tetap terjaga, selanjutnya diinkubasi selama satu bulan. Setelah itu, tanah diambil sebagian dan diletakan pada plastik untuk dikering-anginkan selama 1 minggu, lalu dimasukkan ke dalam plastik sebanyak $100 \mathrm{~g}$ untuk di kirim ke Laboratorium Instalasi Tanah, Maros, untuk proses analisis kemasaman tanah ( $\mathrm{pH}$ dan $\mathrm{Al}-\mathrm{dd}), \mathrm{P}$ tersedia dan $\mathrm{N}$ total tanah.

\section{HASIL DAN PEMBAHASAN}

\section{Reaksi (pH) Tanah}

Hasil analisis ragam menunjukkan bahwa pengaruh perlakuan kompos ela sagu dan mikroorganisme antagonis nyata secara mandiri dalam meningkatkan $\mathrm{pH}$ tanah, sedangkan interaksi keduanya tidak berpengaruh nyata. 
Tabel 1. Reaksi (pH) tanah akibat pemberian kompos ela sagu pada Ultisol

\begin{tabular}{lc|lc}
\hline $\begin{array}{l}\text { Kompos Ela Sagu }(\mathrm{K}) \\
(\mathrm{g} / \mathrm{kg} \text { tanah })\end{array}$ & $\mathrm{pH}$ Tanah & $\begin{array}{l}\text { Mikroorganisme Antagonis }(\mathrm{A}) \\
(20 \mathrm{~mL})\end{array}$ & $\mathrm{pH} \mathrm{Tanah}$ \\
\hline K0 $(0)$ & $4,68 \mathrm{a}$ & A0 (tanpa mikroorganisme) & $4,90 \mathrm{a}$ \\
$\mathrm{K} 1(15)$ & $4,95 \mathrm{~b}$ & A1 (Trichoderma $\mathrm{sp})$ & $5,12 \mathrm{~b}$ \\
$\mathrm{~K} 2(22.5)$ & $5,28 \mathrm{c}$ & A2 (Azotobacter $\mathrm{sp})$ & $5,39 \mathrm{c}$ \\
K3 $(30)$ & $5,62 \mathrm{~d}$ & & \\
\hline
\end{tabular}

Keterangan: angka-angka yang diikuti dengan huruf yang sama tidak berbeda nyata pada uji beda Duncan 0,05 .

Pada Tabel 1 menunjukkan bahwa antar pemberian dosis kompos memberikan pengaruh yang nyata terhadap peningkatan $\mathrm{pH}$ tanah; makin tinggi dosis makin bertambah nilai $\mathrm{pH}$ tanah, yaitu dari 4.68 menjadi 5.62 pada dosis $30 \mathrm{~g} / \mathrm{kg}$ tanah. Demikian juga pemberian mikroorganisme antagonis baik Trchoderma sp maupun Azotobacter sp berbeda nyata dengan tanpa perlakuan dalam meningkatkan $\mathrm{pH}$ Tanah. Pemberian mikroorganisme Azotobacter sp dapat meningkatkan $\mathrm{pH}$ tanah tertinggi, yaitu 5.39.

Reaksi $(\mathrm{pH})$ tanah awal Ultisol rendah/masam (4.7) akibat dari adanya ion $\mathrm{Al}^{3+}$ tersedia bebas di dalam larutan tanah sehingga akan terhidrolisis dengan air dan selalu menghasilkan ion $\mathrm{H}^{+}$. Konsentrasi ion $\mathrm{H}^{+}$terus meningkat sehingga membuat tanah menjadi masam ( $\mathrm{pH}$ rendah). Tetapi setelah pemberian kompos ela sagu ke dalam tanah maka akan terjadi dekomposisi oleh mikroorganisme baik dalam tanah maupun oleh pemberian mikroorganisme antagonism, sehingga menghasilkan asam-asam organik (humus) yang mempunyai kemampuan untuk mengkhelat ion $\mathrm{Al}^{3+}$ dan $\mathrm{H}^{+}$dalam ikatan yang kuat, akibatnya $\mathrm{pH}$ tanah akan meningkat karena ion-ion $\mathrm{OH}^{-}$dalam keadaan bebas di larutan tanah (Hardjowigeno., 2007), dan ini juga sesuai hasil penelitian sebelumnya (Kaya, 2009 dan 2012).

\section{Aluminium Dapat Ditukar (Al-dd) Tanah}

Hasil analisis ragam menunjukkan bahwa bahan organik (kompos ela sagu), dengan mikroorganisme antagonis secara mandiri memberikan pengaruh terhadap penurunan $\mathrm{Al}$ dalam tanah begitupun dengan interaksi keduanya.

Pada Tabel 2 menunjukkan bahwa makin tinggi dosis kompos ela sagu yang diberikan bersama-sama dengan mikroorganisme antagonis, baik Trichoderma $\mathrm{sp}$ maupun Azotobacter sp, maka terjadi penurunan Al-dd tanah. Pemberian dosis $30 \mathrm{~g} / \mathrm{kg}$ tanah berbeda nyata dengan tanpa maupun diberi kompos ela sagu dan pemberian $15 \mathrm{~g} / \mathrm{kg}$ tanah, tetapi tidak berbeda dengan nyata dengan dosis $22.5 \mathrm{~g} / \mathrm{kg}$ tanah. Sebaliknya pemberian mikroorganisme nntagonis Trichoderma $\mathrm{sp}$ atau Azotobacter sp dapat menurunkan Al-dd tanah, bila tanpa pemberian kompos ela sagu. Sedangkan Azotobacter sp bila diberikan bersama-sama dengan kompos ela sagu pada dosis $15 \mathrm{~g} / \mathrm{kg}$ tanah menunjukkan perbedaan nyata dengan yang tanpa maupun diberi Trichoderma sp dalam menurunkan Al-dd tanah. Secara keseluruhan, kombinasi antara pemberian kompos ela sagu $30 \mathrm{~g} / \mathrm{kg}$ tanah dan mikroorganisme Azotobacter $\mathrm{sp}$ dapat menurunkan Al-dd tertinggi, yakni dari 1.79 menjadi $0.48 \mathrm{cmol}^{(+)} / \mathrm{kg}$. Namun, secara statistic dapat dilihat bahwa kombinasi pemberian kompos ela sagu $22.5 \mathrm{~g} / \mathrm{kg}$ tanah dengan mikroorganisme Azotobacter $\mathrm{sp}$ sudah cukup dalam menurunkan Al-dd tanah.

Pemberian kompos ela sagu yang diberikan bersama-sama dengan mikroorganisme antagonis (Trichoderma sp atau Azotobacter sp) berpengaruh nyata terhadap penurunan Al-dd tanah, karena adanya kompos dan aktivitas mikroba mampu menghasilkan asam organik dari proses dekomposisi bahan organik, sehingga asam organik dapat mengkhelat $\mathrm{Al}$ terlarut yang pada gilirannya dapat mengurangi ketersediaan $\mathrm{Al}$ yang berlebihan di dalam tanah yang bisa menyebabkan racun bagi tanaman. Asam-asam organik ini dapat mengurangi daya racun $\mathrm{Al}$ pada tanah masam dengan cara mengikat $\mathrm{Al}$ sebagai senyawa kompleks sehingga Al tidak terhidrolisis lagi (Tripathi et al., 2008; Aryanto et al., 2015).

\section{P Tersedia Tanah}

Hasil analisis ragam menunjukkan bahwa pemberian kompos ela sagu, mikroorganisme antagonis (Trichoderma $\mathrm{sp}$ dan Azotobacter $\mathrm{sp}$ ), maupun interaksi keduanya berpengaruh nyata terhadap peningkatan fosfor $(\mathrm{P})$ tersedia tanah.

Hasil uji beda sebagaimana disajikan pada Tabel 3 menunjukkan bahwa pemberian kompos ela sagu bersama mikroorganisme Azotobacter sp dapat meningkatkan P-tersedia tanah secara nyata bersamaan dengan peningkatan dosis sampai $30 \mathrm{~g} / \mathrm{kg}$ tanah. Sedangakan bila kompos ela sagu diberikan dengan Trichoderma sp juga dapat meningkatkan P-tersedia tanah secara nyata dengan dosis kompos $30 \mathrm{~g} / \mathrm{kg}$ tanah. Ini berbeda dengan perlakuan tanpa mikroorganisme, di mana pemberian kompos dosis $22.5 \mathrm{~g} / \mathrm{kg}$ tanah berbeda nyata dengan tanpa maupun diberi dosis $15 \mathrm{~g} / \mathrm{kg}$ tanah, tetapi tidak berbeda dengan dosis kompos $30 \mathrm{~g} / \mathrm{kg}$ tanah di dalam meningkatkan P-tersedia tanah. Sebaliknya pemberian mikroorganisme Azotobacter sp maupun Trichoderma sp, bersama-sama dengan kompos ela sagu berbeda nyata dalam meningkatkan P-tersedia tanah, sejalan dengan peningkatan dosis kompos ela sagu. Pemberian kombinasi terbaik dalam meningkatkan Ptersedia tanah tertinggi adalah kompos ela sagu dosis 30 $\mathrm{g} / \mathrm{kg}$ tanah dengan mikroorganisme Azotobacter sp, yakni sebesar $24.00 \mathrm{ppm}$. 
Tabel 2. Al-dd tanah akibat perlakuan kompos ela sagu dengan mikroorganisme antagonis pada Ultisols

\begin{tabular}{|c|c|c|c|}
\hline \multirow{2}{*}{$\begin{array}{l}\text { Kompos Ela Sagu }(\mathrm{K}) \\
\qquad \mathrm{g} / \mathrm{kg} \text { tanah })\end{array}$} & \multicolumn{3}{|c|}{$\begin{array}{l}\text { Mikroorganisme Antagonis (A) } \\
(20 \mathrm{~mL})\end{array}$} \\
\hline & $\begin{array}{c}\mathrm{A} 0 \\
\text { (tanpa mikroorg) }\end{array}$ & $\begin{array}{c}\mathrm{A} 1 \\
\text { (Trichoderma } \mathrm{sp})\end{array}$ & $\begin{array}{c}\mathrm{A} 2 \\
\text { (Azotobacter } \mathrm{sp})\end{array}$ \\
\hline & & $\left(\mathrm{cmol}_{(+)}\right.$per kg) & \\
\hline K0 (0) & $\begin{array}{c}1.79 \mathrm{a} \\
\mathrm{A}\end{array}$ & $\begin{array}{c}1.31 \mathrm{a} \\
\mathrm{B}\end{array}$ & $\begin{array}{c}1.16 \mathrm{a} \\
\mathrm{C}\end{array}$ \\
\hline K1 (15) & $\begin{array}{c}1.02 \mathrm{~b} \\
\mathrm{~A}\end{array}$ & $\begin{array}{c}0.93 \mathrm{~b} \\
\mathrm{~A}\end{array}$ & $\begin{array}{c}0.76 \mathrm{~b} \\
\mathrm{~B}\end{array}$ \\
\hline K2 (22.5) & $\begin{array}{c}0.66 \mathrm{c} \\
\mathrm{A}\end{array}$ & $\begin{array}{c}0.60 \mathrm{c} \\
\mathrm{A}\end{array}$ & $\begin{array}{c}0.53 \mathrm{c} \\
\mathrm{A}\end{array}$ \\
\hline K3 (30) & $\begin{array}{c}0.56 \mathrm{c} \\
\mathrm{A}\end{array}$ & $\begin{array}{c}0.51 \mathrm{c} \\
\mathrm{A}\end{array}$ & $\begin{array}{c}0.48 \mathrm{c} \\
\mathrm{A}\end{array}$ \\
\hline
\end{tabular}

Keterangan: angka-angka yang diikuti dengan huruf yang sama pada baris atau kolom tidak berbeda nyata pada uji beda Duncan 0.05 .

Tabel 3. P-tersedia tanah akibat pemberian kompos ela sagu dengan mikroorganisme antagonis pada Ultisols

\begin{tabular}{|c|c|c|c|}
\hline \multirow{2}{*}{$\begin{array}{l}\text { Kompos Ela Sagu }(\mathrm{K}) \\
\qquad(\mathrm{g} / \mathrm{kg} \text { tanah })\end{array}$} & \multicolumn{3}{|c|}{$\begin{array}{l}\text { Mikroorganisme Antagonis (A) } \\
20 \mathrm{~mL}\end{array}$} \\
\hline & $\begin{array}{c}\mathrm{A} 0 \\
\text { (kontrol) }\end{array}$ & $\begin{array}{c}\mathrm{A} 1 \\
\text { (Trichoderma } s p)\end{array}$ & $\begin{array}{c}\mathrm{A} 2 \\
(\text { Azotobacter } s p)\end{array}$ \\
\hline & & $(\mathrm{ppm})$ & \\
\hline K0 (0) & $\begin{array}{c}8.50 \mathrm{a} \\
\mathrm{A}\end{array}$ & $\begin{array}{c}9.33 \mathrm{a} \\
\mathrm{A}\end{array}$ & $\begin{array}{c}14.33 \mathrm{a} \\
\mathrm{B}\end{array}$ \\
\hline K1 (15) & $\begin{array}{c}17.00 \mathrm{~b} \\
\mathrm{~A}\end{array}$ & $\begin{array}{l}20.00 \mathrm{c} \\
\mathrm{B}\end{array}$ & $\begin{array}{l}20.00 \mathrm{c} \\
\mathrm{B}\end{array}$ \\
\hline $\mathrm{K} 2(22.5)$ & $\begin{array}{c}16.00 \mathrm{~b} \\
\mathrm{~A}\end{array}$ & $\begin{array}{c}15.67 \mathrm{~b} \\
\mathrm{~A}\end{array}$ & $\begin{array}{c}16.67 \mathrm{~b} \\
\mathrm{~A}\end{array}$ \\
\hline K3 (30) & $\begin{array}{l}15.33 \mathrm{~b} \\
\mathrm{~A}\end{array}$ & $\begin{array}{c}20.00 \mathrm{c} \\
\mathrm{B}\end{array}$ & $\begin{array}{l}24.00 \mathrm{~d} \\
\mathrm{C}\end{array}$ \\
\hline
\end{tabular}

Keterangan: angka-angka yang diikuti dengan huruf yang sama pada baris atau kolom tidak berbeda nyata pada uji beda Duncan 0.05 .

Tabel 4. N-total tanah akibat pemberian kompos ela sagu dengan mikroorganisme antagonis pada Ultisols

\begin{tabular}{|c|c|c|c|}
\hline \multirow{2}{*}{$\begin{array}{c}\text { Kompos Ela Sagu } \\
\text { (K) } \\
\text { (g/kg tanah) }\end{array}$} & \multicolumn{3}{|c|}{$\begin{array}{l}\text { Pemberian Mikroba Antagonis (A) } \\
20 \mathrm{~mL}\end{array}$} \\
\hline & $\begin{array}{c}\mathrm{A} 0 \\
\text { (Tanpa Mikroorganisme) }\end{array}$ & $\begin{array}{c}\mathrm{A} 1 \\
\text { (Trichoderma) }\end{array}$ & $\begin{array}{c}\mathrm{A} 2 \\
\text { (Azotobacter) }\end{array}$ \\
\hline & & $(\%)$ & \\
\hline K0 (0.0) & $\begin{array}{c}0.09 \mathrm{a} \\
\mathrm{A}\end{array}$ & $\begin{array}{c}0.09 \mathrm{a} \\
\mathrm{A}\end{array}$ & $\begin{array}{c}0.08 \mathrm{a} \\
\mathrm{A}\end{array}$ \\
\hline K1 (15) & $\begin{array}{c}0.10 \mathrm{a} \\
\mathrm{A}\end{array}$ & $\begin{array}{c}0.10 \mathrm{a} \\
\mathrm{A}\end{array}$ & $\begin{array}{c}0.15 \mathrm{~b} \\
\mathrm{~B}\end{array}$ \\
\hline K2 (22.5) & $\begin{array}{c}0.16 \mathrm{~b} \\
\mathrm{~A}\end{array}$ & $\begin{array}{c}0.16 \mathrm{~b} \\
\mathrm{~A}\end{array}$ & $\begin{array}{c}0.18 \mathrm{c} \\
\mathrm{B}\end{array}$ \\
\hline K3 (30) & $\begin{array}{c}0.15 \mathrm{~b} \\
\mathrm{~A}\end{array}$ & $\begin{array}{c}0.18 \mathrm{c} \\
\mathrm{B}\end{array}$ & $\begin{array}{c}0.20 \mathrm{~d} \\
\mathrm{C}\end{array}$ \\
\hline
\end{tabular}

Keterangan: angka-angka yang diikuti dengan huruf yang sama pada baris atau kolom tidak berbeda nyata pada uji beda Duncan 0.05 .

Pemberian kompos ela sagu bersama-sama mikroorganisme antagonis dapat meningkatkan Ptersedia tanah karena bahan organik yang diberikan ke dalam tanah akan mengalami proses dekomposisi, baik oleh mikroba yang sudah ada di dalam tanah maupun mikroorganisme antagonis yang diberikan bersamasama kompos ke dalam tanah; dan ini akan menghasilkan unsur hara tersedia, seperti N, P, dan K di larutan tanah (Hasanudin 2003). Selain itu hasil dekomposisi bahan organik akan menghasilkan asamasam organik yang dapat mengkhelat ion $\mathrm{Al}^{3+}$ dan $\mathrm{Fe}^{3+}$ sehingga menurunkan aktivitas $\mathrm{Al}$ dan $\mathrm{Fe}$ di dalam larutan tanah. Dengan demikian, $\mathrm{P}$ yang diikat oleh ion $\mathrm{Al}^{3+}$ maupun $\mathrm{Fe}$ akan dilepaskan ke larutan tanah sehingga $\mathrm{P}$ tersedia akan meningkat (Foth, 1998; Kaya, 2009; Khairuna et al., 2015). 


\section{Nitrogen (N) Total Tanah}

Hasil analisis ragam menunjukkan bahwa secara mandiri baik kompos ela sagu, mikroorganisme antagonis (Trichoderma sp dan Azotobacter sp), maupun interaksi keduanya berpengaruh nyata terhadap peningkatan $\mathrm{N}$ total tanah.

Hasil uji beda sebagaimana disajikan pada Tabel 4 menunjukkan bahwa pemberian kompos ela sagu bersama mikroorganisme Azotobacter sp maupun Trichoderma sp dapat meningkatkan N-total tanah secara nyata bersamaan dengan peningkatan dosis sampai $30 \mathrm{~g} / \mathrm{kg}$ tanah. Sebaliknya pemberian mikroorganisme Azotobacter sp maupun Trichoderma sp bersama-sama dengan kompos ela sagu berbeda nyata dalam meningkatkan $\mathrm{N}$-total tanah, sejalan dengan peningkatan dosis kompos ela sagu. Pemberian kombinasi terbaik dalam meningkatkan N-total tanah tertinggi adalah pemberian kompos ela sagu dengan dosis $30 \mathrm{~g} / \mathrm{kg}$ tanah dengan mikroorganisme Azotobacter sp, yakti sebesar $0.20 \%$.

Nitrogen merupakan hara makro utama yang sangat penting untuk pertumbuhan tanaman. Nitrogen diserap oleh tanaman dalam bentuk ion $\mathrm{NO}_{3}{ }^{-}$atau $\mathrm{NH}_{4}{ }^{+}$ dari tanah. Berdasarkan hasil penelitian diketahui kompos ela sagu (K3 atau sampai $30 \mathrm{~g} / \mathrm{kg}$ tanah) yang di berikan bersama-sama dengan mikroorganisme antagonis (Azotobacter $s p$ atau Trichoderma $s p$ ) mampu menaikkan $\mathrm{N}$ total tanah. Bahan organik yang mengalami proses dekomposisi mengandung berbagai unsur hara. Menurut Stevenson (1994) dan Sugiyanto et al (2008), bahan organik secara langsung merupakan sumber hara $\mathrm{N}$ dan secara tidak langsung bahan organik membantu penyediaan unsur hara $\mathrm{N}$ melalui fiksasi $\mathrm{N}_{2}$ dengan cara menyediakan energi bagi bakteri penambat $\mathrm{N}_{2}$, seperti bakteri Azotobacter sp; dengan demikian, aplikasi inokulum Azotobacter sp dapat meningkatkan $\mathrm{N}$ total tanah, serapan $\mathrm{N}$ tanaman, jumlah anakan dan hasil padi (Danapriatna et al, 2010; Hindersah et al, 2014).

\section{KESIMPULAN}

Dari hasil penelitian tersebut dapat disimpulkan bahwa:

1. Kompos ela sagu meningkatkan $\mathrm{pH}$ tanah; peningkatan $\mathrm{pH}$ ini tidak bergantung pada aktivitas mikroorganisme antagonis. Dalam hal ini nilai $\mathrm{pH}$ tertinggi, yaitu 5.62, tercapai pada dosis kompos 30 $\mathrm{g} / \mathrm{kg}$ tanah.

2. Mikroorganisme antagonis meningkatkan $\mathrm{pH}$ tanah; peningkatan $\mathrm{pH}$ ini tidak bergantung pada dosis kompos ela sagu. Dalam hal ini $\mathrm{pH}$ tanah tertinggi, yaitu 5.39, tercapai pada mikroorganisme Azotobacter sp.

3. Konsentrasi P-tersedia meningkat dengan pemberian kompos; peningkatan P-tersedia ini bergantung pada aktivitas mikroorganisme antagonis. P-tersedia paling tinggi, yaitu $24 \mathrm{ppm}$, tercapai pada $30 \mathrm{~g} / \mathrm{kg}$ tanah dengan $20 \mathrm{~mL}$ Azotobacter sp.

4. Konsentrasi Al-dd menurun dengan pemberian kompos ela sagu; penurunan konsentrasi Al-dd ini bergantung pada aktivitas mikroorganisme antagonis. Dalam hal ini aktivitas mikroorganisme antagonis hanya nyata pada dosis kompos rendah, yaitu $15 \mathrm{~g} / \mathrm{kg}$ tanah atau tanpa kompos. Pengaruh Azotobacter sp lebih nyata dibandingkan Trichoderma sp dalam menurunkan konsentrasi Aldd.

5. Konsentrasi N-total meningkat dengan pemberian kompos ela sagu; peningkatan ini bergantung pada aktivitas mikroorganisme antagonis. Dalam hal ini aktivitas mikroorganisme antagonis terutama Azotobacter sp lebih nyata pada dosis kompos 30 $\mathrm{g} / \mathrm{kg}$ tanah. Konsentrasi N-total paling tinggi, yaitu $0.2 \%$, tercapai pada kombinasi kompos $30 \mathrm{~g} / \mathrm{kg}$ tanah dengan $20 \mathrm{~mL}$ Azotobactr $\mathrm{sp}$.

\section{DAFTAR PUSTAKA}

Aryanto A, Triadiati, Sugiyanta. 2015. Pertumbuhan dan produksi padi sawah dan gogo dengan pemberian pupuk hayati berbasis bakteri pemacu tumbuh di tanah masam. Jurnal Ilmu Pertanian Indonesia 20: 229-235. DOI: 10.18343/jipi. 20.3.229

Danapriatna, N., R. Hindersah, dan Y. Satrio. 2010. Pengembangan Pupuk Hayati Azotobacter dan Azospirillium Untuk Meningkatkan Produktivitas dan Efisiensi Penggunaan Pupuk N Di atas 15\% Pada Tanaman Padi. Laporan Penelitian KKP3T. LPPM Universitas Islam 45. Bekasi.

Foth, H. D. 1998. Dasar-Dasar Ilmu Tanah. Gadjah Mada University Press, Yogyakarta.

Hardjowigeno, S. 2007. Ilmu Tanah. Akademika Pressindo, Jakarta.

Hardjowigeno, S. 1995. Klasifikasi Tanah dan Pedogenesis. Akademi Presindo, Jakarta.

Hasanudin, 2003. Peningkatan ketersediaan dan serapan $\mathrm{N}$ dan $\mathrm{P}$ serta hasil tanaman jagung melalui inokulasi mikoriza, Azotobacter dan bahan organik pada Ultisols. Jurnal Ilmu-Ilmu Pertanian Indonesia 5(2): 83-89.

Hindersah R, D. A. Sulaksana dan D. Herdiyantoro. 2014. Perubahan kadar N tersedia dan populasi Azotobacter di rizosfer sorgum (Sorghum bicolor L.) yang ditanam di dua ordo tanah dengan inokulasi Azotobacter sp. Jurnal Agrologia 3(1): $10-17$

Kaya, E. 2012. Pengaruh pemberian kompos ela sagu dan pupuk ABG Bunga-Buah terhadap P tersedia serapan $\mathrm{P}$ serta pertumbuhan tanaman jagung (Zea mays L.) pada Inceptisols. Jurnal Buana Sains 14(2): 113-122. DOI: https://doi.org/ 10.33366/bs.v12i1.145.

Kaya, E. 2003. Perilaku Fosfat dalam tanah, serapan Fosfat, dan Hasil Jagung (Zea mays L.) Akibat Pemberian Pupuk Fosfat Dengan Amelioran 
pada Typic Dystrudepts. Disertai Doktor. Universitas Padjajaran, Bandung.

Kaya, E., J.A. Putinella dan F. Puturuhu. 2010. Pengaruh Pemberian Kompos Ela Sagu Dan Pupuk sp-36 Terhadap Perilaku P Dalam Tanah, Serapan P, dan Hasil Jagung (Zea mays L.) Pada Ultisols. Laporan Penelitian Hibah Penelitian Multi Year Tahun Anggaran 2010.

Kaya, E. 2009. Ketersediaan fosfat, serapan fosfat dan hasil tanaman jagung (Zea mays L) akibat pemberian bokashi ela sagu dengan pupuk fosfat pada Ultisols. Jurnal Ilmu Tanah dan Lingkungan 9(1): 30-36.

Khairuna, Syafruddin, dan Marlina. 2015. Pengaruh fungi mikoriza arbuskular dan kompos pada tanaman kedelai terhadap sifat kimia tanah. Jurnal Floratek 10(1): 1-9.

Sanchez, P. A. 1992. Properties and Management of Soils in the Tropics. John Wiley \& Sons, Inc, New York.

Soplanit, M.C. 2011. Pengaruh Bokashi Ela Sagu Pada Berbagai Waktu Kematangan dan Pupuk SP-36 Terhadap Fraksi-Fraksi P (Al-P, Fe-P, Ca-P, dan RS-P), Serapan $\mathrm{P}$ dan pertumbuhan Tanaman
Jagung (Zea mays L.) Pada Tanah Ultisol Telaga Kodok. Skripsi. Fakultas Pertanian, Universitas Pattimura, Ambon.

Stevenson, F.J. 1994. Humus Chemeistry Genesis, Compasition, Reactions (Second Edition). John Wiley \& Sons, Inc. New York.

Sugiyanto, J.B. Baon, dan K.A. Wijaya. 2008. Sifat kimia tanah dan serapan hara tanaman kakao akibat bahan organik dan pupuk fosfat yang berbeda. Pelita Perkebunan 24(3): 183-284.

Susilawati, Mustoyo, E. Budhisurya, R.C.W. Anggono dan B.H. Simanjuntak. 2013. Analisis kesuburan tanah dengan indikator mikroorganisme tanah pada berbagai sistem penggunaan lahan di plateau Dieng. Agric, Jurnal Ilmu Pertanian 25(1): 64-72.

Tripathi R.D., S. Dwivedi, M.K. Shukl, S. Mishra, S. Srivastava, R. Singh, U.N. Rai and D.K. Gupta. 2008. Role of blue green algae biofertilizer in ameliorating the nitrogen demand and fly-ash stress to the growth and yield of rice (Oryza sativa L.) plants. Chemosphere 70(10): 19191929. DOI: http://doi.org/d875z3. 